\title{
Hepatoprotective Effect of Caffeic Acid Phenethyl Ester (CAPE) on Carbon Tetrachlo- ride (CCI4) Induced Acute Hepatotoxicity in Rats
}

\section{Karbontetrakloridle Akut Hepatotoksite Olusturulan Ratlarda Caffeic Acid Phenethyl Ester (CAPE)'in Karaciğerî Koruyucu Etkisi}

Süleyman Özen¹, Hayal Oral², Hanefi Özbek ${ }^{3}$

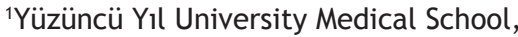
Department of Pathology, Van, Turkey

${ }^{2}$ Adana Goverment Hospital, Department of Pathology, Adana, Turkey

${ }^{3}$ The Ministry of Health, Drug Agency, Ankara, Turkey

Eur J Basic Med Sci 2011;1(1):7-12

Received: 31.08 .2010

Accepted: 27.09 .2010

Correspondence (Yazıșma Adresi): Süleyman Özen

Department of Pathology, Yüzüncü Yıl University Medical School, Van, Turkey Tel: 905056752033

E-mail: suleymanozen65@yahoo.com

\section{ABSTRACT}

In this study, hepatoprotective activity of CAPE, which has antiinflammatory, anticancer, antiviral, and immunomodulatory effects, was investigated in the CCl4 induced liver injury model in rats. Twenty-one Sprague Dawley rats were divided into the three groups: Control $(n=7), C C l 4(n=7), C C l 4+$ CAPE $(n=7)$. The serum levels of AST, ALT, LDH, and bilirubin were measured on the first and last day (10 th day) in all experimental animals. Histopathological examinations were carried out in the rats sacrificed on the tenth day. For histopathological evaluation, livers of all rats were removed and processed for light microscopy. The levels of unconjugated bilirubin, AST, ALT, ALP in CCI4 group were markedly higher than those in the control group $(p<0.01, p<0.01, p<0.001$ and $p<0.05$ respectively). The values of these parameters in $\mathrm{CAPE}+\mathrm{CCl} 4$ group were lower than those in $\mathrm{CCl} 4(p<0.01, p<0.05, p<0.05, p<0.001$ respectively). Histopathological findings also corfirmed that CCl4 induced hepadic damage and support the wiev that CAPE has a hepatoprotective activity. The results of this study indicate that CAPE has a hepatoprotective action in acute liver injury.

Key words: Carbon tetrachloride(ccl4), acute hepatotoxicity, caffeic acid phenethyl ester(cape), rat. 


\section{ÖZET}

$\mathrm{Bu}$ çalıșmanın amacı antiinflamatuar, antikanser, antivitral ve immünomodulatuar etkileri olan CAPE'nin karaciğeri koruyucu aktivitesini CCI4 ile olușturulan karaciğer hasar modelinde araştırmaktır. Yirmibir Sprague Dawley ratlar üç gruba ayrıldı: Kotrol (n:7), CCl4 (n:7), CCI4 + CAPE (n:7). Bütün hayvanlarda birinci ve son günde (onuncu gün) $A S T, A L T, L D H$ ve bilirubin serum düzeyleri ölçüldü. Histopatolojik incelemeler onuncu günde sakrifiye edilen ratlarda yapıldı. Histopatolojik değerlendirme için ratların karaciğerleri çıkarıldı ve ışıı mikroskopu için işlemden geçirildi. Unconjugated bilirubin, AST, $A L T$, ALP düzeyleri CCI4 grupta kontrol grubundakilerden belirgin olarak daha yüksekti (sırasıyla $p<0.01, p<0.01, p<0.001$ ve $p<0.05)$. Bunların değerleri $\mathrm{CAPE}+\mathrm{CCl} 4$ grupta $\mathrm{CCl} 4$ grubundakilerden daha düșüktü (sırasiyla $p<0.01, p<0.05$, $p<0.05, p<0.001)$. Histopatolojik bulgular aynı zamanda CCI4 ile olușturulan hepatic zarara sebep olduğunu ve CAPE'nin karaciğeri koruyucu aktiviteye sahip olduğunu gösterdi. Bu çalışmanın sonuçları akut karaciğer hasarında CAPE'nin karaciğeri koruyucu etkiye sahip olduğuna işaret eder.

Anahtar kelimeler: Karbon tetrachlorid, akut hepatotoksisite, caffeic acid phenethyl ester, rat.

\section{INTRODUCTION}

Numerous substance are known to cause liver damage. One of these chemicals is carbon tetrachloride (CCl4) which is a xenobiotic that induces hepatotoxicity in humans as well as in animals $(1,2)$. Carbon tetrachloride (CCl4), awell-known model compound for producing chemical hepatic injury, is biotransformed by hepatic microsomal cytochrome $\mathrm{P} 450$ to trichloromethyl-free radicals (CCI3) (3-5) In addition, CCl4 induces elevated levels of hepatic enzymes in serum that are markers of liver cell damage (6). Furthermore, histopathological changes occur in the liver after CCl4 administration (6,7-10).

Caffeic acid phenethyl ester (CAPE) is an active component of honeybee propolis extracts and has been used for many years as a folk medicine (11) CAPE is a small, lipidsoluble flavonoid-like compound that has anti-inflammatory (12) antiviral, immunomodulatory (13) antitumoral (14) neuroprotective (15) and anti-atherosclerotic (16) and antioxidant activities (17). It has been found that CAPE has protective effects against carbon tetrachloride- induced liver in the crhonic period (18) and kidney injuries in rats $(19,20)$ and mice $(21)$ and against cisplatin- induced hepatic oxidative damage (22). In vitro studies showed that CAPE is effective against experimentally produced liver toxicity (21). It has antiproliferative and antioxidant properties and has been shown to inhibit lipooxygenase activities as well as suppress lipid peroxidation (23-27). It was shown in a previous study that CAPE preserved heart tissue from doxorubicin-induced oxidant injury (28).

The aim of the present study was to investigate whether treatment of rats with CAPE prior to $\mathrm{CCl} 4$ administration prevents $\mathrm{CCl} 4$-induced acute hepatotoxicity. For this purpose, we designed to determine the histopathological effects of $\mathrm{CCl} 4$ and the possible protective effect of CAPE on acute phase tissue damage of rat liver.

\section{MATERIALS AND METHODS}

\section{Animals and treatment}

Twenty-one Sprague Dawley rats, initially weighing $150-170$ gr. at 14-16 weeks old, were used in this study. The animals were fed with a Standard diet, kept on a physiological day/night rhythm and maintained in an ambient temperature of $22{ }^{\circ} \mathrm{C}$ during the experimental procedures. The experiments were performed in accordance with the Guide for the Care and Use of Laboratory Animals.29 Rats were randomly divided into three groups: rats given $\mathrm{CCl} 4(0.8 \mathrm{ml} / \mathrm{kg}$ body weight per $1 \mathrm{ml}$ olive oil, Merk KgaA, 64271 Darmstad, Germany) as a CCl4-induced acute hepatotoxicity model ( $n=7)$; rats given $\mathrm{CCl} 4$ plus CAPE $(20 \mu \mathrm{gr} / \mathrm{kg}$ body weight per $1 \mathrm{ml}$ olive oil) ( $n=7)$; and rats given isotonic saline solution $(0.2 \mathrm{ml} / \mathrm{kg}$ body weight) alone as a control group $(\mathrm{n}=$ 7). Application of CAPE in CCl4 induced acute hepatotoxicity

The CAPE was synthesized by the standard method of Grunberger11 and administered intraperitoneally once a day at a dose of $20 \mu \mathrm{gr} / \mathrm{kg}$ body weight. The first dose of CAPE was given 3 day prior to $\mathrm{CCl} 4$ injection and continued until sacrifice.

\section{Anesthesia}

Rats were anesthetized with a cocktail of ketamine hydrochloride $(50 \mathrm{mg} / \mathrm{kg})$ and xylazine $(5 \mathrm{mg} / \mathrm{kg})$ which were administered intraperitoneally (i.p.) before the animals were sacrificed.

\section{Serum biochemistry}


Table 1. Biochemical parametes in serum and statistical comparisons of the groups.

\begin{tabular}{|c|c|c|c|c|c|c|}
\hline \multirow[t]{2}{*}{ Parameters } & \multicolumn{2}{|c|}{ Control } & \multicolumn{2}{|c|}{$\mathrm{CCl} 4$} & \multicolumn{2}{|c|}{$C C l 4+C A P E$} \\
\hline & $n$ & Mean $\pm S E M$ & $n$ & Mean $\pm S E M$ & $n$ & Mean \pm SEM \\
\hline$A S T$ & 7 & $193.40 \pm 11.88$ & 7 & $2192.16 \pm 592.99 b$ & 7 & $1008.00 \pm 162.79 d$ \\
\hline$A L T$ & 7 & $63.80 \pm 2.96$ & 7 & $1363.83 \pm 348.62 c$ & 7 & $685.66 \pm 136.48 d$ \\
\hline$A L P$ & 7 & $354.25 \pm 19.36$ & 7 & $487.50 \pm 48.59 a$ & 7 & $567.83 \pm 22.41 c$ \\
\hline Unconjugated bilirubin & 7 & $0.112 \pm 0.007$ & 7 & $0.495 \pm 0.114 b$ & 7 & $0.198 \pm 0.032 e$ \\
\hline Conjugated bilirubin & 7 & $0.050 \pm 0.004$ & 7 & $0.213 \pm 0.099 b$ & 7 & $0.041 \pm 0.005 e$ \\
\hline
\end{tabular}

Results os post hoc LSD (least-squares difference test), a:Statistical difference with control group at $p<0$. 05. b:Statistical difference with control group at $p<0.01$. $c$ :Statistical difference with control group at $p<0.001$. d: Statistical difference with CCl4 group at $p<0.05$. e: Statistical difference with CCl4 group at $p<0.01$.

ALT, AST and ALP serum activities were measured on the first and last day (10 th day) in all experimental animals to assess hepatotoxicity. ALT, AST, ALP, conjugated and unconjugated bilirubin activities in blood serum were evaluated by an autoanalyzer using spectrophotometric diagnostic kits.

\section{Histopathological analysis of liver}

Liver tissue specimens were fixed in neutral formalin solution (10\%). Tissue specimens were embedded in paraffin wax and sectioned (thickness, $3 \mu \mathrm{m}$ ). For histopathological evaluation, sections were stained with hematoxylin and eosin (H\&E) and Masson's trichrome, and examined with a BX50-3 Olympus light microscope (Olympus Optical, Tokyo, Japan). Number of mitotic and apoptotic cells, and ballon degeneration was calculated per 10 high-power fields.

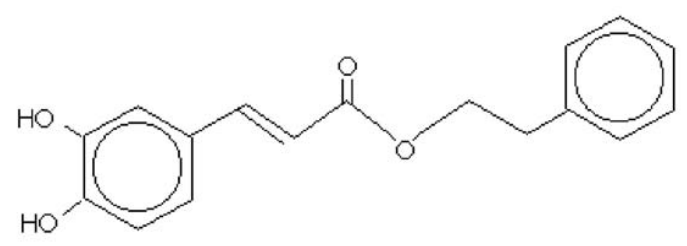

Figure 1.The structure of caffeic acid phenethyl ester. Note that the two hydroxyl groups located in the first ring show antioxidant activity. The antioxidant activity of the compound depends not only on the hydroxyl groups or catechol rings but also on the partition coefficient or hydrophobicity of CAPE.

\section{Statistical analysis}

Data are expressed as means \pm standard deviation. The one-way analysis of variance (ANOVA) and post hoc multiple comparison tests (least-squares difference, Tukey's HSD) were performed on the data of biochemical and histopathological variables to examine the differences among groups. All analyses were made using the SPSS statistical software package; $\mathrm{p}<0.05$ was considered statistically significant.

\section{RESULTS}

The effects of CAPE pretreatment on the CCl4-induced elevation of serum levels ALT, AST, ALP, unconjugated and conjugated bilirubin are shown in Table 1. CCl4 caused hepatotoxicity in rats, as indicated by the increases in ALT, AST and ALP serum levels. However, CAPE pretreatment reduced the $\mathrm{CCl} 4$-induced elevations in

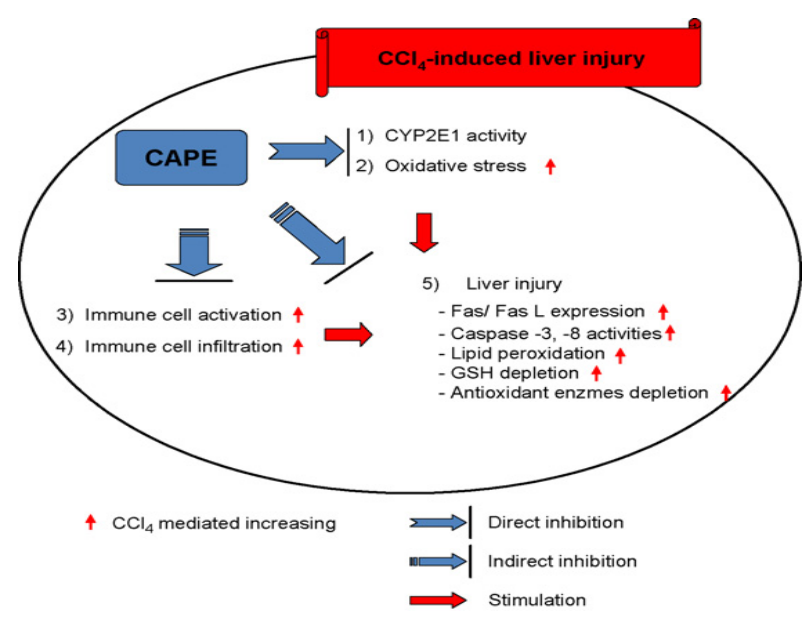

Figure 2.Diagram shows that protective mechanisms of CAPE against CCl4-induced liver damage. 
Table 2. Histopathological parameters and statistical comparisons of the groups.

\begin{tabular}{|c|c|c|c|c|c|c|}
\hline \multirow[t]{2}{*}{ Parameters } & \multicolumn{2}{|c|}{ Control } & \multicolumn{2}{|c|}{$\mathrm{CCl} 4$} & \multicolumn{2}{|c|}{$\mathrm{CCl} 4+\mathrm{CAPE}$} \\
\hline & $n$ & Mean $\pm S E M$ & $n$ & Mean $\pm S E M$ & $n$ & Mean $\pm S E M$ \\
\hline Balloon degeneration & 7 & $0.12 \pm 0.10$ & 7 & $31.50 \pm 4.00 b$ & 7 & $3.10 \pm 0.23 d$ \\
\hline Apoptosis & 7 & $0.10 \pm 0.10$ & 7 & $1.4 \pm 0.30 a$ & 7 & $0.50 \pm 0.22 c$ \\
\hline Mitoses & 7 & $0.090 \pm 0.10$ & 7 & $0.40 \pm 0.22 e$ & 7 & $0.20 \pm 0.13$ \\
\hline
\end{tabular}

Results os post hoc Tukey's HSD Test, a: Statistical difference with control group at $p<0.01$. b: Statistical difference with control group at $p<0.001$. $c$ : Statistical difference with CCl4 group at $p<0.05$. d: Statistical difference with CCl4 group at $p<0.001$. e: Statistical difference with control group at $p<0.05$.

ALT, AST, unconjugated and conjugated bilirubin serum levels (Table 1).

Livers of rats in the control group showed a normal histological appearance. Histopathological analysis showed classic histopathology in livers of rats treated with CCl4. Hepatic ballon degeneration, focal necrosis, and apoptotic cells were observed in rat livers. However, the severe hepatic lesions (necrosis, ballon degeneration,) induced by $\mathrm{CCl} 4$ were remarkably ameliorated by CAPE. Consistent with this histopathological data, apoptosis was also either markedly prevented or minimized in CAPE given group (Table 2). According to our biochemical and histopathological findings, it is concluded that CAPE treatment prevents CCl4-induced liver damage in rats.

\section{DISCUSSION}

$\mathrm{CCl} 4$, which is an intrinsic hepatotoxin, was used to induce hepatic damage in this study since it has previously been shown to exert its toxic effects on the liver $(1,2)$. Administration of CCl4 to rats causes severe liver injury which is recognized histopathologically together with an increase in serum levels of the hepatic enzymes AST and ALT, which are indices of liver cell damage (6). Liver injury induced by $\mathrm{CCl} 4$ is a common model for screening the hepatoprotective activity of drugs because this chemical is a potent hepatotoxin and a single exposure can rapidly lead to severe hepatic necrosis and steatosis (30-32). Increases in serum AST, ALT and ALP levels by $\mathrm{CCl} 4$ have been attributed to hepatic structural damage because these enzymes are normally localized to the cytoplasm and are released into the circulation after cellular damage has occurred (33).

Some studies have shown that $\mathrm{CCl} 4$ administration causes increased serum levels of AST, ALT and ALP $(6,7,9,34,35)$. The hepatotoxicity of $\mathrm{CCl} 4$ was confirmed in our study by a significant elevation of serum levels of
AST, ALT, ALP, conjugated and unconjugated biluribin. Additionally, it has been reported that $\mathrm{CCl} 4$ causes necrosis $(7,9,35-37)$ steatosis and ballon degeneration of hepatocytes, increase in mitotic activity (6) in liver. It has also been reported that $\mathrm{CCl} 4$ causes apoptosis in liver $(9,10,38,39)$. We also observed all of those findings in $\mathrm{CCl} 4$-induced acute hepatotoxicity in rats.

Previous experimental studies have shown that lipid peroxidation can be prevented by CAPE in spinal cord and kidney after ischemia reperfusion $(25,40)$. We have previously shown that CAPE administration prevents cisplatin-induced nephrotoxicity in rats (20). Similarly, Fadillioglu et al. (28) have reported that CAPE inhibits cardiotoxicity induced by doxorubicin in rat. Additionally, CAPE scavenges reactive oxygen species (ROS) and guards against GSH depletion in mice brain tissues (15). CAPE has these protective effects on the basis of antioxidant actions, but the exact mechanisms of anti-oxidant properties of CAPE are not known yet. However, it has been speculated that CAPE may affect transcription and/or translation of genes and gene products of anti-oxidant enzymes (20). It can be attributed to the presence of the two phenolic groups in its catechol ring (40). Like some other antioxidant compounds (i.e. vitamins $C$ and E), CAPE can show antioxidant activity with its two hydroxyl groups located in one of the ring structures (Figure 1) (20).

In the present study, CAPE treatment significantly reduced elevated serum levels of AST, ALT, ALP, conjugated and unconjugated biluribin. Our results are supported by several reports that CAPE has protective effects against oxidative damage in various tissues (18,41-43). On the other hand, some studies has revealed that CAPE has inhibitory effect on neutrophil sequestration into the tissue protecting the tissue from ROS produced in huge amount in relevant tissues by neutrophils (44). Generally, neutrophils accumulate in liver damaged by toxicants, such as diethylnitrosamine and $\mathrm{CCl} 4$, and 
then release inflammatory cytokines, like tumor necrosis factor, interleukin (IL)-1 and IL-6, which also have toxic effects in CCl4-induced liver injury (45). In previous studies, CAPE exhibited anti-atherosclerotic and anti-inflammatory activities via inhibition of NF-_B activity (46) and protected against Fas-mediated cell apoptosis (47). Consistent with these data, our results showed that CAPE dramatically prevented CCl4-induced liver injury by depleting balloon degeneration and preventing hepatic apoptosis.

In the recent study, Lee and colleagues (21) demonstrated that CAPE has potent hepatoprotective effects against CCl4-induced hepatic damage in mice. In this study, the hepatoprotective effects of CAPE may be caused by its ability to block the bioactivation of $\mathrm{CCl} 4$ by inhibiting CYP2E1 activity, in combination with its ability to scavenge free radicals. In addition, CAPE may be able to block infiltration and activation of neutrophils through its anti-inflammatory and anti-caspases activities by inhibiting Fas/FasL protein expression in CCl4-induced hepatic damage (Figure 2) (21).

In conclusion, We showed the protective effect of CAPE both histologically and biochemically in CCl4-induced hepatic damage. The results of this study indicate that CAPE has a hepatoprotective action in CCl4-induced acute liver injury.

\section{REFERENCES}

1. Stacey N, Priestly BG. Dose-dependent toxicity of CCl4 in isolated rat hepatocytes and the effects of hepatoprotective treatments. Toxicol Appl Pharmacol 1978;45:29-39.

2. Kodavanti PR, Joshi UM, Young RA, Meydrech EF, Mehendale HM. Protection of hepatotoxic and lethal effects of CCl4 by partial hepatectomy. Toxicol Pathol 1989;17:494-505.

3. Brattin WJ, Glende Jr EA, Recknagel RO. Pathological mechanisms in carbon tetrachloride hepatotoxicity. J Free Radic Biol Med 1985; 1:27-38.

4. Rechnagel RO, Glende Jr EA. Carbon tetrachloride hepatotoxicity: an example of lethal cleavage. CRC Crit Rev Toxicol 1973;2:263-97.

5. Rikans LE, Hornbrook KR, Cai Y. Carbon tetrachloride hepatotoxicity as a function of age in female Fischer 344 rats. Mech Ageing Dev 1994;76:89-99.

6. Teocharis SE, Margeli AP, Skaltsas SD, Spiliopoulou CA, Koutselinis AS. Induction of metallothionein in the liver of carbon tetrachloride intoxicated rats: an immunohistochemical study. Toxicology 2001;161:129-38.

7. Naziroglu M, Cay M, Ustundag B, Aksakal M, Yekeler H.
Protective effects of vitamin $E$ on carbon tetrachloride-induced liver damage in rats. Cell Biochem Funct 1999;17:253-9.

8. Natsume M, Tsuji $H$, Harada A, Akiyama M, Yano $T$, Ishikura H, Nakanishi I, Matsushima K, Kaneko S, Mukaida $N$. Attenuated liver fibrosis and depressed serum albumin levels in carbon tetrachloride-treated IL-6-deficient mice. J Leukoc Biol 1999;66: 601-8.

9. Wang GS, Eriksson LC, Xia L, Olsson J, Stal P. Dietary iron overload inhibits carbon tetrachloride-induced promotion in chemical hepatocarcinogenesis: effects on cell proliferation, apoptosis and antioxidation. J Hepathol 1999;30:689-98.

10. Zalatnai A, Sarosi I, Rot A, Lapis K. Inhibitory and promoting effects of carbon tetrachloride-induced liver cirrhosis on the diethylnitrosamine hepatocarcinogenesis in rats. Cancer Lett 1991;57:67-73.

11. Grunberger D, Banerjee R, Eisinger K, et al. Preferential cytotoxicity on tumor cells by caffeic acid phenethyl ester isolated from propolis. Experientia 1988;44:230-32.

12. Chen YJ, Shiao MS, Wang SY. The antioxidant caffeic acid phenethyl ester induces apoptosis associated with selective scavenging of hydrogen peroxide in human leukemic HL-60 cells. Anticancer Drugs 2001;12:143-49.

13. Park EH, Kahng JH. Suppressive effects of propolis in rat adjuvant arthritis. Arch Pharm Res 1999;22:554-8.

14. Nagaoka T, Banskota AH, Tezuka Y, Midorikawa K, Matsushige K, Kadota S. Caffeic acid phenethyl ester (CAPE) analogues: potent nitric oxide inhibitors from the Netherlands propolis. Biol Pharm Bull 2003;26:487-91.

15. Ilhan A, Iraz M, Gurel A, Armutcu F, Kyol O. Caffeic acid phenethyl ester exerts a neuroprotective effect on CNS against pentylenetetrazol-induced seizures in mice. Neurochem Res 2004;29:2287-92.

16. Hishikawa K, Nakaki T, Fujita T. Oral flavonoid supplementation attenuates atherosclerosis development in apolipoprotein E-deficient mice. Arterioscler Thromb Vasc Biol 2005;25:442-6.

17. Rao C, Desai D, Kaul B, Amin S, Reddy BS. Effect of caffeic acid esters on carcinogen-induced mutagenicity and human colon adenocarcinoma cell growth. Chem Biol Interact 1992;84:277-290.

18. Kus I, Colakoglu N, Pekmez H, Seckin D, Ogeturk M, Sarsilmaz M. Protective effects of caffeic acid phenethyl ester (CAPE) on carbon tetrachlorideinduced hepatotoxicity in rats. Acta. Histochem 2004;106:289-97.

19. Ogeturk M, Kus I, Colakoglu N, Zararsiz I, Ilhan N, Sarsilmaz M. Caffeic acid phenethyl ester protects kidneys against carbon tetrachloride toxicity in rats. J. Ethnopharmacol 2005;97:273-80.

20. Ozen S, Akyol O, Iraz M, et al. Role of caffeic acid phenethyl ester, an active component of propolis, against cisplatin-induced nephrotoxicity in rats. J. Appl. Toxicol. 2004;24: 27-35.

21. Lee KJ, Choi JH, Khanal T, Hwang YP, Chung YC, Jeong HG. Protective effect of caffeic acid phenethyl ester against 
carbon tetrachloride-induced hepatotoxicity in mice. Toxicology 2008;248:18-24.

22. Iraz M, Ozerol E, Gulec M, et al. Protective effect of caffeic acid phenethyl ester (CAPE) administration on cisplatin-induced oxidative damage to liver in rat. Cell Biochem Funct 2006;24:357-61

23. Sud'ina GF, Mirzoeva OK, Pushkareva MA, Korshunova GA, Sumbatyan NV, Varfolomeev SD. Caffeic acid phenethyl ester as a lipoxygenase inhibitor with antioxidant properties. FEBS Lett 1993; 329: 21-24.

24. Hepsen IF, Bayramlar H, Gultek A, Ozen S, Tilgen F, Evereklioglu C. Caffeic acid phenethyl ester to inhibit posterior capsule opacification in rabbits. J Cataract Refract Surg 1997;23: 1572- 6.

25. Hepsen IF, Er H, Cekic O. Topically applied water extract of propolis to suppress corneal neovascularization in rabbits. Ophthal Res 1999;31:426-31.

26. Ilhan A, Koltuksuz U, Ozen S, Uz E, Ciralik H, Akyol O. The effects of caffeic acid phenethyl ester (CAPE) on spinal cord ischemia/reperfusion injury in rabbits. Eur $J$ Cardiothorac Surg 1999;16:458-63.

27. Koltuksuz U, Ozen S, Uz E, Aydinc M, Karaman A, Gultek $A$, et al. Caffeic acid phenethyl ester (CAPE) prevents intestinal reperfusion injury in rats. J Pediatr Surg 1999;34:1458- 62.

28. Fadillioglu $E$, Oztas $E$, Erdogan $H$, et al. Protective effects of caffeic acid phenethyl ester on doxorubicin-induced cardiotoxicity in rats. J Appl Toxicol 2004; 24: 47-52.

29. National Institutes of Health, USA. Guide for the Care and Use of Laboratory Animals. DHEW Publication No. 85-23, $\mathrm{NIH}, 1985$.

30. Brautbar N, Williams II J. Industrial solvents and liver toxicity: risk assessment, risk factors and mechanisms. Int J Hyg Environ Health 2002;205:479-91.

31. Brent JA, Rumack BH. Role of free radicals in toxic hepatic injury. II. Are free radicals the cause of toxin-induced liver injury? J Toxicol Clin Toxicol 1993;31:173-96.

32. Manibusan MK, Odin M, Eastmond DA. Postulated carbon tetrachloride mode of action: a review. J Environ Sci Health 2007;25:185-209.

33. Recknagel RO, Glende Jr, EA, Dolak JA, Waller RL. Mechanisms of carbon tetrachloride toxicity. Pharmacol Ther 1989;43:139-54

34. Mansour MA. Protective effects of thymoquinone and desferrioxamine against hepatotoxicity of carbon tetrachloride in mice. Life Sci 2000;66:2583-91.

35. Al-Shabanah OA, Alam K, Nagi MN, Al-Rikabi AC, AlBekairi AM. Protective effect of aminoguanidine, a nitric oxide synthase inhibitor, against carbon tetrachloride induced hepatotoxicity in mice. Life Sci 2000;66:265-70.

36. Zalatnai A, Sarosi I, Rot A, Lapis K. Inhibitory and promoting effects of carbon tetrachloride-induced liver cirrhosis on the diethylnitrosamine hepatocarcinogenesis in rats. Cancer Lett 1991;57:67-73.

37. Burr AW, Carpenter MR, Hines JE, Gullick WJ, Burt AD. Intrahepatic distribution of transforming growth factoralpha (TGF-a) during liver regeneration following carbon tetrachloride-induced necrosis. J Pathol1993;170:95-100.

38. Shi J, Aisaka K, Ikawa Y, Wake K. Evidence of hepatocyte apoptosis in rat liver after the administration of carbon tetrachloride. Am J Pathol 1998;153:515-25.

39. Cabre M, Ferre N, Folch J, Paternain JL, Hernandez M, del Castillo D, Joven J, Camps J. Inhibition of hepatic cell nuclear DNA fragmentation by zinc in carbon tetrachloride-treated rats. J Hepathol 1999;31: 228-34.

40. Ozyurt H, Irmak MK, Akyol O, Sogut S. Caffeic acid phenethyl ester changes the indices of oxidative stress in serum of rats with renal ischemia - reperfusion injury. Cell Biochem Funct 2001;19:259-63.

41. Sahin S, Sogut S, Ozyurt H, Uz E, Ithan A, Akyol O. Tissue xanthine oxidase activity and nitric oxide levels after spinal cord ischemia/reperfusion injury in rabbits: comparison of caffeic acid phenethyl ester (CAPE) and methylprednisolone. Neurosci Res Commun 2002;31:111- 21.

42. Irmak MK, Koltuksuz U, Kutlu NO, Yagmurca M, Ozyurt $H$, Akyol O. The effect of caffeic acid phenethyl ester on ischemia- reperfusion injury in comparison with a-tocopherol in rat kidneys. Urol Res 2001;29:190-3.

43. Altug ME, Serarslan $Y$, Bal $R$, et al. Caffeic acid phenethyl ester protects rabbit brains against permanent focal ischemia by antioxidant action: a biochemical and planimetric study. Brain Res 2008;1201:135-142.

44. Scapagnini $G$, Foresti $R$, Calabrese $V$, et al. Caffeic acid phenethyl ester and curcumin: a novel class of heme oxygenase-1 inducers. Mol Pharmacol 2002;61:1264.

45. Naugler WE, Sakurai T, Kim S. Gender disparity in liver cancer due to sex differences in MyD88-dependent IL-6 production. Science 2007;317:121-4.

46. Orban Z, Mitsiades N, Burke Jr TR, Tsokos M, Chrousos GP. Caffeic acid phenethyl ester induces leukocyte apoptosis, modulates nuclear factor-kappa B and suppresses acute inflammation. Neuroimmunomodulation 2000;7:99-105.

47. Choi K, Han YH, Choi C. N-Acetyl cysteine and caffeic acid phenethyl ester sensitize astrocytoma cells to Fas-mediated cell death in a redox-dependent manner. Cancer Lett 2007;257:79-86. 